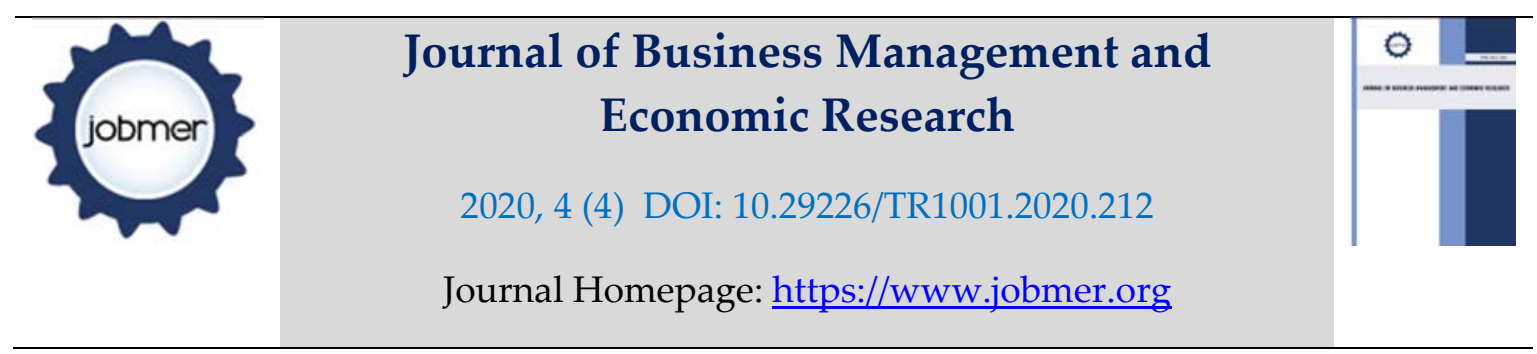

\title{
Effect of Firm Characteristics on Dividend Policy in Firms Listed in Nairobi Security Exchange, Kenya
}

\author{
Kibet K. Buigut \\ Department of Accounting and Finance \\ School of Business and Economics \\ Moi University \\ buigutkibet@gmail.com

\section{Neddy Cherotich Soi} \\ Department of Accounting and Finance \\ School of Business and Economics \\ Moi University
}

\begin{abstract}
The main aim of the paper was to establish the mediating effect of firm characteristics on dividend policy. The study is informed by Catering theory of dividends. This study was informed longitudinal research design. The target population comprising forty three (43) banks will be retrieved from the Central Bank of Kenya (CBK) and Nairobi Securities Exchange (NSE). Each bank was analyzed annually for 10 years giving 430 firm year observations. A census approach was used to include commercial banks registered with the CBK and banks listed in the NSE. The data collection instrument to be used in this study was content/document analysis. a panel data framework using fixed and random effect was used to test the hypotheses. Findings from random model showed that firm portability, ownership, leverage and liquidity had significant effect on dividends policy. Thus, based on the evidence from study findings, firms with higher profitability and higher liquidity will pay more dividends. In addition, banks with high level of ownership concretion and liquidity have high probability for paying dividends. The key contribution of this study is that it helps shed additional light on the inconclusive issues regarding the effects of ownership structure, profitability, liquidity and leverage on dividend policy in banks. In addition, Financial managers in banks can use the findings to improve the payment of dividends, investment policy and capital budgeting decisions of banks. Consequently, government and relevant regulatory agencies would formulate policies and regulatory framework that take cognizance of the influence of firm characteristics on dividend policy. This is the first study that investigates ho bank specific characteristics affect the propensity to pay dividends and dividend payout along with long-term relationships in a single study Keywords: Profitability, ROA, Liquidity, Dividends Policy
\end{abstract}

\section{Suggested Citation:}

Buigut, K. K. \& Soi, N.C. (2020). Effect of Firm Characteristics on Dividend Policy in Firms Listed in Nairobi Security Exchange, Kenya. Journal of Business Management and Economic Research (JOBMER), Vol: 4, Issue: 4, 299-317. 
Journal of Business Management and Economic Research (JOBMER), Vol.4, Issue.4, pp.299-317

\section{Introduction}

According to Al-Masum, (2014) there is a potential impact by Dividend policy to investors. Dividend policy is also a factor in evaluating the ability of a firm to produce optimistic money movement. Stouraitis and $\mathrm{Wu}$ (2004) propose that excess investment difficulties of organization can be done away with, through dividend policy. Investors can use dividend policy in decrease of broker charges and also to help as a sign to a company's health. Certainly, dividend strategy is one of the vital tools of a business's strategies (Miko and Kamardin, 2015). According to Sharma and Wadhwa, (2013), Dividend policy is defined as payment plan that a company's follows in deciding the scope and design of issuing profit to investors over-time. Dividend plan research can be traced back to the powerful work of Miller and Modilgiani (1961) they display that dividend strategy has no result on the worth of the business given a capital market that is perfect with usual conduct and perfect certainty and borrowing decisions and investment given. DeAngelo and DeAngelo (2006) re-scrutinizes, report and challenges the idea of dividend strategy being irrelevance in the original Miller and Modigliani (1961) ideal and gives a the foundation for the importance of dividend strategy.

Baker and Wurgler (2004) in their study, dividends in decision making by investors seems to be considered as one of the important indicators. Various investors look stocks that pay dividends. Overall, a dividend is what investors like in a firm. Some earlier research shows that investors like to see the similar amount of dividends or rise over time. Tse (2005) proposes that dividends are used as a sign for companies' future projections. Some international business context and managers' behavioral features has been used to examine dividend payout design. There is correlation among dividend strategy, agency system and business exact characteristics (Porta et al. 2006).

Corporate dividend policy and firm value can be affected both directly and indirectly by some factors in firm characteristics. For example, Al-Najjar (2009); Al-Shubiri (2011) cited that profitability, company size, ownership, financial power, and investment opportunity as key determinants of dividend policy. Similarly, Hafeez Ahmed \& Attiya Javid (2009) also listed factors affecting dividend policy as the following, ownership, leverage, company size, company age, profitability, investment opportunities, and liquidity as factors affecting dividend policy. Botoc and Pirtea (2014) find that DPR in 16 emerging markets is positively determined by liquidity and profitability. While Kuzucu (2015) claims that DPR in Turkish listed firms is negatively determined by profitability, while liquidity is regarded as a unimportant forecaster. However, in spite of many researches being carried out on the determining factor of dividend strategy in listed 
Journal of Business Management and Economic Research (JOBMER), Vol.4, Issue.4, pp.299-317

companies, these researches have conveyed mixed results which are not constant and lacking any consensus on the greatness and direction of profitability, liquidity, ownership and leverage on dividend policy mostly in developing economies more so on companies registered in N.S.E

The state of Kenya since the early 1990s, has pursued a thoughtful divestiture strategy intended at diminishing government ownership of organizations with a vision of inviting private sector contribution in running of the inexperienced government organization. Prediction was given that this plan would improve performance of these corporations due infusion of more effective management designs. The uniqueness of firm tenure in Kenya by other companies is that the holding companies are usually big organizations with the power to restructure their division/associate processes to bail out non-performing associates (Ongore, 2011).

Various studies have tried to discover matters concerning the dividend dynamics and dividend policy determinants. Study by Black, (1976), Brealey and Myers, (2006) states, there is no most accepted clarification on bonus conduct of companies. The subject of dividend in Kenya has been a puzzle as most companies listed at the NSE mostly pay cash bonus shares and dividends at the end of second quarter and the last dividend payout at the end of the financial year. Companies pay an extra dividend when there is unexpected income. However, various firms do not pay dividends for numerous years because to financial difficulties. Largely, most companies listed at the NSE have perfect and well-defined dividend strategies that are in tandem with the overall dividend exercise in the industry. The difference in payment of dividends among businesses listed in NSE raises a question of dividend policy determinant in Kenya banking sector. There is need to study and establish a correlation among company features and dividend strategy in regard to the above difficulties.

\section{Theoretical explanations of dividend policy}

\section{Bird-in-the-Hand Theory}

This theory says that dividends are significant. Dividend income plus capital gains equals total returns. Gordon (1963) and Lintner (1962) according to this calculation are supposed that overall return would reduce as a firm's dividends payout increase. There is an investor concern that when a company raises its payout share, business's forthcoming capital profit will disappear because the retained income that the firm re-invest the corporate will be less (Eugene, 1990). Gordon (1963) and Lintner (1962) claimed that decision making related to stocks, shareholders value dividends in contrast to capital gains. This theory of Bird-in- 
Journal of Business Management and Economic Research (JOBMER), Vol.4, Issue.4, pp.299-317

the-hand may sound conversant as it comes from early proverb that a bird in the hand is more valuable than two in the bush. The bird in the hand is dividends and in the bush is the capital gain in regard to this theory.

\section{Signaling Theory}

The notion that mediators send statistics to the principal so as to produce a good affiliation is termed as signaling theory. Company executives have information which is more actual than company's investors, but are usually unwilling to give clear information to investors. Therefore, dividend policy is purposely used for information and also as a indication of the business's upcoming forecast. Information dissemination to investors about the company's value is leading role that is played by dividend policy Miller and Rock (1985) and Li and Zhao (2008).

Bhattacharya, (1979); Miller and Rock, (1995) says that signaling concept recommends that information to investors about firm earnings in future is delivered by dividends. This signal is reliable only if it is not too expensive for lesser quality companies to imitate. Predictions of signaling theory is supported by several evidence studies from empirical researches. For example, Ofer and Siegal (1987) says that dividend declarations are associated with rise stock price, whereas dividend slashes are connected with stock price decline. In the same vein, Bancel et al.,(2009), in an assessment of CFOs from 16 countries in Europe and Brav et al.,(2005), in a research of CFOs from US, discovered a proof proposing of the existence of unwillingness by executives to change dividend strategy. Thus, dividend strategy is an expensive sign that may alter shareholder's views about a company's earnings projections.

\section{Catering Theory of Dividends}

The dividend theory of catering is the most recent concept that was developed by Baker and Wurgler (2004). Reducing research undertaken by Modigiliani and Miller (1961), of the supposition of faultless markets and well-organized markets and considering mental and formal reasons, Baker and Wurgler (2004) came up with a simple theoretical model. First, on dividend-paying stocks they claimed that some shareholders have less informed and perhaps time changing demand. Second, buying and selling of stocks plays unsuccessfully in setting apart the payers and non-payers dividend prices. Thirdly, investors demand is sensibly provided for by directors by compensating investors when they put prices higher on payers, and they do not compensate when investors prefer non-payers. 
Journal of Business Management and Economic Research (JOBMER), Vol.4, Issue.4, pp.299-317

Dividend theory of catering proposes that actual monetary markets are inadequate and ineffective, and companies make dividends beginning and continuation verdicts by taking care of the shareholders' dividends demand (Tsuji, 2010). Normally, shareholders' dividends demand can be taken as the difference between non-payers' and payers' Market to Book (M/B) ratio, which business executives can know via financial markets. Hence, According to Tsuji, (2010) catering model foresees that when the payers' M/B ratio is higher than the nonpayers' $\mathrm{M} / \mathrm{B}$ ratio business executives make dividend beginnings or dividend continuations by taking care of shareholders' dividend demands.

\subsection{Review of Literature (Development of the Hypothesis)}

This section focuses on the applicable empirical proof, expansion of the study theories and operationalization of the research variables that supports determinants of dividend policy.

\section{Profitability}

The equation of measuring profitability according to Amidu and Abor (2006), Boțoc and Pirtea (2014), Wang et al. (2016) and Al-Kayed (2017) is the yield on equity ratio. Net income of a firm comprises of dividends that are apportioned to shareholders. According to Chang, (2009); Abor and Bokpin, (2010) company predictions shows firms offer higher dividends when the firm's profitability and cash flow is higher. Hafeez \& Attiya, Javid (2009) examined 320 non-financial companies listed in Karachi Stock Exchange during the period of 2001 to 2006 on the altering features and factors of dividend strategy. For the research Lintner (1956) dividend ideal was used and its lengthy versions in dynamic setting. Firms with larger dividend payout were found to be profitable with more steady net incomes and can have the funds for greater free cash movements. Explanation of the relationship between profitability and dividends may be provided also by the pecking order theory and signaling theory Fama and French, (2002); Yarram and Dollery, (2015). Kimie and Pascal (2011) and Kuzucu (2015) found that profitability as a factor with an adverse effect on corporation dividend strategy. In contrast, Amidu and Abor (2006), Al-Malkawi (2007), Al-Najjar (2011), Bokpin (2011), Patra et al. (2012) and Botoc and Pirtea (2014) recognize profitability as a factor with a positive effect on company dividend strategy.

H1: High profitable companies will have a higher probability of of paying dividends. 
Journal of Business Management and Economic Research (JOBMER), Vol.4, Issue.4, pp.299-317

\section{Liquidity}

Patra et al. (2012), Kuzucu (2015), Boțoc and Pirtea (2014), Turner et al. (2013) and Al-Kayed (2017) in their study defines current percentage as current assets divided by current obligations as our liquidity measure. Dividend policy has been investigated and shows liquidity as one of its factor. Lintner (1956) in his qualitative research of 28 firm executives recognized liquidity as a less commonly known determinant. Baker et al. (1985), developed a new argument which says that liquidity is the key factor of dividend strategy. "Liquidity hypothesis of dividends," according to Banerjee et al. (2007) is a negative correlation between liquidity and dividend policy, an ideal supported by Zhiqiang et al. (2015). Baker and Kapoor (2015) disclose that robust support for the liquidity model for stock dividends in Indian situation. In a comparative research of Australia and Japanese firms, Ho (2003) conversed that out of all the retreated variables of power, incertainty, asset mix, liquidity, profitability, degree, and development, the dividend policies are certainly affected by magnitude in Australia and liquidity in Japan and negatively by risk in Japan only.

The determinant of dividend payment ratio of the Indian Information Technology industry was observed Anil and Kapoor, (2008). They also found that liquidity and beta (year-to-year variability in incomes) as per the proofs collected for seven years were found to be significant causes. In contrast, Abdelsalam et. al., (2008) also studied the dividend policy of 50 listed companies in Egypt for the period 2003-2005. Important positive correlation between dividend policy and liquidity were shown to exist from the results of the research, therefore grounded on this inconstancy of results on the relationship between divided policy and liquidity. The study theorized that;

$\mathrm{H}_{2}$ : High liquid firms will have a higher probability of paying dividends.

\section{Ownership}

Following Ankudinov and Lebedev (2016) and Setiawan et al. (2016), tenure organization is here applied to mean the ratio of percentage controlled by firm largest investors. According to Shleifer and Vishny (1997), La Porta et al. (2000), Claessens et al. (2000) and Faccio et al. (2001), most firms' shows focused tenure and are managed by families, governments, or single owners. Due to this reason, payments of dividends are made to aggravate agency challenges between directors and shareholders. Hence, ownership organization need also be considered a determinant of dividend policy. In Turkey, Al-Najjar and Kilincarslan (2016) revealed that a small dividends payment in Turkey is connected with foreign ownership 
Journal of Business Management and Economic Research (JOBMER), Vol.4, Issue.4, pp.299-317

and government ownership. In contrast, Setiawan et al. (2016) recommend that dividend policy affected positively by the overall ownership arrangement.

$H_{3}$ : Highly ownership concentrated firms will have a higher probability of paying dividends.

\section{Leverage}

Leverage is calculated as total debt to total equity ratio according to (Al-Malkawi 2007, Abor and Bokpin 2010, Patra et al. 2012, Boţoc and Pirtea 2014, Kuzucu 2015 and Al-Kayed 2017). As discoursed by Taranto (2002) a relation between financial powers with dividends policy raises from limiting debt contracts (including limitations of dividends payment) of creditor to look after its benefits. Rozeff (2002) says that transaction charges and the certainty of the companies is increases due to high leverage. Profitability companies with a strong leverage ratio have high secure payments for using exterior financing. Dividend policy is impacted but also liquidity situation of a firm is affected. Companies with insufficient level of cash are less likely to pay dividends than companies with high level of cash. Thus, the likelihood a company will pay money when dividends are positively related to liquidity (Kaźmierska-Jóźwiak, 2015).

Best dividend policy together with optimal leverage is researched in certain theories, such as, one established by Fan and Sundaresan (2000) which rotates around the flow-based insolvency. Evasion happens when the voucher to be paid is higher than shifting cash level. Best dividend policy look after distribution differences between the cash and the voucher, when positive. Financial policies, such as leverage and dividend, will impact administrative strategy and decision of directors to join as owner of the company. Lintner (1956) recognizes financial obligations as a less significant determinant of firm dividend policy. Rozeff (1982) expresses that a firm with high financial leverage is likely to have low payouts proportions, contrary to business deal costs connected with outside financing. According to this argument, Al-Malkawi (2007) recommends that companies with high financial obligation ratios are likely to pay smaller dividends. In accordance with Lintner's (1956) consequences, Abor and Bokpin (2010) says that exterior financing, financial obligation and financial power are less significant determinant of dividend policy. Bokpin (2011), Patra et al. (2012) and Arko et al. (2014) recognize financial power as a main cause of company dividend policy. Yusof and Ismail (2016) identify financial obligation as a negative determinant of firm dividend policy in Malaysia. Centered on the beyond mixed outcomes on consequence of leverage on dividend strategy, this research theorized that; 
Journal of Business Management and Economic Research (JOBMER), Vol.4, Issue.4, pp.299-317

\section{H4: High leveraged firms will have a higher probability of paying dividends.}

\section{Control variables}

Big companies are more likely to pay dividends due to easy access to capital markets (Ho, 2003; Aivazian, Booth and Cleary, 2003). According to the agency charge theory, the widespread ownership arrangement in larger companies lessens shareholders' abilities to run financing activities, causing in more asymmetric information and higher agency charges. Al-Malkawi (2007) therefore recognizes company's size as an important factor of dividend strategy. Al-Najjar (2011) and Bokpin (2011) castoff any important effect of company size on corporate dividend strategy. However, Harada and Nguyen (2011) recognize company size as an adverse factor in the Japanese setting. Patra et al. (2012), Kuzucu (2015) and Yusof and Ismail (2016) recognize company size as a positive factor of dividend strategy.

\section{Material and methods}

This research adopted longitudinal research plan which involves tracking changes over time on a broad range of population members. The objective population included 43 banks under central bank of Kenya. Empirical analysis is of 10 years period from 2005 to 2015. A census approach was used, and thus the sampling frame of 43 banks from 2005-2015. Ultimately, 430 firm-year data of 43 banks were included in the sample (unbalanced panel data). An unbalanced panel is one where there are a different number of observations for each cross section unit (or vice versa). These observations may be contiguous, or there may be holes in the data (Kwak, 2011). That is, for the example dataset, the study used seven years of data for First Community Bank (2008 to 2015) and six years for UBA Kenya Bank Limited (2009 - 2015). The data collection instrument to be used in this study was content/document analysis guide. The study was conducted using secondary sources which were achieved by analyzing the content of financial reports of 43 banks quoted in NSE and registered with Central bank of Kenya. This was suitable for this study because all the audited information about the companies will be readily available for the public as required by the company law of Kenya Act.

\section{Measurement of Variables}

According to Hussainey et al., (2011), dividend payout ratio is the ratio of dividends per share to earnings per share for all available years. Salari et al., (2014) also calculated dividend payout ratio by dividing dividends per share to earnings per share and the average is taken. 
Return on assets (ROA), the ratio of operating income to total assets, is used to control for firm's profitability. Firms with higher profitability tend to pay higher dividends than firms with lower profitability. Therefore, a positive relationship between ROA and dividends is predicted ((Thanatawee, 2013).

Liquidity was measured using current ratio which simply compares all liquid assets with all current liabilities. The current ratio is calculated by dividing current assets by current liabilities (Khidmat and Rehman, 2014).

Ownership was a proxy of ownership concentration and measured by the percent of shares owned by the five largest shareholders (TOP5) (Harada and Nguyen, 2011) and Khan , 2006).

Leverage (LEV) is total debt divided by book value of total assets. Since firms with higher debt are more likely to be financially constrained and should be less able to pay dividends, a negative relationship between leverage and dividend payments is expected accordingly ((Thanatawee, 2013).

Firm size (SIZE) is the logarithm of total assets. Compared with smaller firms, larger firms tends to be more mature, have higher free cash flows, and are more likely to pay higher dividends. Thus, a positive relationship between firm size and dividends is expected (Thanatawee, 2013). Firm age will be measured using firm age foundation or incorporation (Albitar, 2015).

Table 1. Measurement of Variables

\begin{tabular}{|c|c|c|c|}
\hline Variables & Indicators & Measurement & References \\
\hline $\begin{array}{l}\text { Dependent Variab } \\
\text { Dividend Payout } \\
\text { Policy }\end{array}$ & DIV & $\begin{array}{l}\text { This is the ratio of dividends per share to } \\
\text { earnings per share for all available years }\end{array}$ & (Hussainey et al. 2011 \\
\hline \multicolumn{4}{|c|}{ Independent Variables } \\
\hline \multicolumn{4}{|c|}{ Firm Characteristics } \\
\hline Profitability & $\mathrm{PF}$ & Net income / total assets & Cole and White(2012) \\
\hline Leverage & LEV & Total debts / total asset & $\begin{array}{l}\text { Thanatawee (2013) } \\
\text { Khidmat and Rehman, }\end{array}$ \\
\hline Liquidity & LIQ & $\begin{array}{l}\text { Current asset/current liabilities } \\
\text { ownership concentration is }\end{array}$ & 2014 \\
\hline Ownership & $\mathrm{CO}$ & $\begin{array}{l}\text { measured by the percent of shares owned by } \\
\text { the five largest shareholders (TOP5) }\end{array}$ & $\begin{array}{l}\text { Harada and Nguyen } \\
\text { (2011) and Khan (2006) }\end{array}$ \\
\hline \multicolumn{4}{|l|}{ Control Variables } \\
\hline Firm Size & FZ & Natural log of total assets & Thanatawee (2013) \\
\hline Firm Age & FA & Years since incorporation & Albitar, 2015 \\
\hline
\end{tabular}


Journal of Business Management and Economic Research (JOBMER), Vol.4, Issue.4, pp.299-317

\section{Model specification}

A panel data framework is used to test the hypotheses. Panel data, as noted by Hsiao (1986), has several distinct advantages: it provides more degrees of freedom, increases variations in the data and thereby reduces the chances of multicollinearity, and makes it possible to control for fixed effects. panel data have the strength of accommodating more observations hence increases the degrees of freedom. In addition, it reduces the problem of collinearity of regressors and modelling flexibility of behaviour differences within and between countries and/or groups or institutions (Biwott, 2011; Hsiao, 2007). Panel data will be analyzed using fixed effect model (FEM) and random effects model (REM). Fixed effects model is used when controlling for omitted variables that differ between individuals but are constant over time. If some omitted variables might be constant over time but vary between individuals, and others might be fixed between individuals but vary over time, then random effects model will be of help in taking the two types into account. The random effects model would be appropriate if data are representative of a sample rather than the entire population, because the individual effect term can be a random outcome rather than a fixed parameter.

According to Lee (2008) in order to compare the usefulness of these models, three tests will be run. First, fixed effects will be tested by $\mathrm{F}$ test and the null hypothesis--all individual effects terms except one are zero-will be rejected at $0.1 \%$ significance level. This suggests that the fixed effects model is better than the pooled OLS model. Second, random effects will be examined by the Lagrange multiplier (LM) test and the null hypothesis--cross-sectional variance components are zero-will be rejected at $0.1 \%$ significance level. This argues in favor of the random effects model against the pooled data model. Finally, Hausman test will be used to compare fixed effects and random effects and the null hypothesis-- there is no significant correlation between the individual effects and the regressors--is rejected at $0.1 \%$ significance level in this test. This confirms the argument in favor of the fixed effects model against the random effects model. In sum, the test results will confirm that the fixed effect model is superior to any other models in dealing with the data

\section{Findings and Discussions}

This section presents the results from all those procedures and analyses. The results presented here are organized under five key sections: descriptive statistics, diagnostic tests, correlation analysis, and hypothesis testing. 
Journal of Business Management and Economic Research (JOBMER), Vol.4, Issue.4, pp.299-317

\section{Descriptive Statistics}

The data comprised of 42 banks observed over a period of ten years that is from the year 2006 to 2016 . The findings are as presented in Table 2. Basing on the results in the table, the dividends paid out to shareholders relative to the company's net income was at a mean of 0.5965 with a maximum value of 3.87 . On the other hand, the profitability levels were at a mean of 6.860 . The minimum profit level was 0.18 while the maximum was 9.4. Furthermore, liquidity levels ranged between 0.2 and 62.91 with an overall mean of 1.545.

Table 2. Descriptive statistics

\begin{tabular}{lccccccc}
\hline & & & & Std. & & \\
& N & Min & Max & Mean & Deviation & Skewness & Kurtosis \\
\hline Dividend & & & & & & & \\
payout & 499 & 0 & 3.87 & 0.5965 & 0.54753 & 2.143 & 5.959 \\
Profitability y & 490 & 0.18 & 9.4 & 6.8602 & 1.66527 & -2.403 & 6.601 \\
Liquidity & 490 & 0.2 & 62.91 & 1.5452 & 5.2335 & 7.473 & 66.411 \\
\hline
\end{tabular}

\section{Robustness Checks}

Prior to selecting which panel regression model to use, and in order to identify potential endogenous variables, some robustness tests have to be carried out, such as a normality tests, multicollinearity, unit root test, test for heteroscedasticity , autocorrelation test ad specification error test For the Jarque-Bera Test, if the p-value is lower than the Chi (2) value then the null hypothesis cannot be rejected. It can therefore be concluded that the residuals are normally distributed. As per Table 2, the chi (2) is 5.37 which is greater than 0.05 meaning that the null hypothesis cannot be rejected. The implication is that there is no violation of the normal distribution assumption of error terms as the residuals are coming out to be normal.

To conduct the heteroskedasticity test, this study uses Breusch-Pagan test for heteroskedasticity. The results shown below Table 3 indicate heteroskedasticity problems. The results required to use the clusterrobust standard error estimator in order to control heteroskedasticity. By using this robust standard error estimator (cluster), the study assumed that observations should be independent across clusters (Rogers, 1993).The study tested heteroskedasticity using Breusch-Pagan / Cook-Weisberg test. The findings indicated that Chi2 (1) was 153.910, p value of 0.060 revealing that null hypothesis was not rejected 
suggesting that assumption of constant variance was not violated. Findings are presented in table 3 . The study tested homoskedasticity using White test. The findings indicated that Chi2 (16) was 112.01, p value of 0.4277 revealing that null hypothesis was rejected suggesting that assumption of homoskedasticity was not violated. Findings are presented in table 3:

Table 3. Normality and Heteroskedasticity Tests

\begin{tabular}{lcc}
\hline & Chi2 & Prob>chi2 \\
\hline Jarque-Bera normality test & 5.57 & 0.0619 \\
Breusch-Pagan / Cook-Weisberg Test for Heteroskedasticity & 153.91 & 0.06 \\
White's Test for heteroskedasticity & 72.15 & 0.057 \\
\hline
\end{tabular}

The results of the VIF test as shown in Table 4 ranged between 1.09 and 4.09. All the variables are less than 10 thereby; our model does not suffer from multicollinearity problems. The VIF values in table 4.6 were less than four meaning that there was no multicollinearity.

Table 4. Multicollinearity

\begin{tabular}{lcc}
\hline Variable & VIF & 1/VIF \\
\hline Profitability & 1.22 & 0.819729 \\
Liquidity & 1.19 & 0.840076 \\
Mean VIF & 2.44 & \\
\hline
\end{tabular}

\section{Unit root test}

Looking at the $p$-values in Table 5, the null hypothesis can be rejected at all conventional significance levels for all the variables of the study, which means that there is no unit root in our data. This implies that the means and variances in our data do not depend on time, hence the application of OLS can produce meaningful results (Gujarati, 2012). 
Table 5. Unit root test

\begin{tabular}{lcccccc}
\hline & $\begin{array}{c}\text { Levin-Lin- } \\
\text { Chu }\end{array}$ & Breitung & $\begin{array}{c}\text { Im- } \\
\text { Pesaran- } \\
\text { Shin }\end{array}$ & $\begin{array}{c}\text { ADF- } \\
\text { Fisher chi } \\
\text { sqaure }\end{array}$ & $\begin{array}{c}\text { PP_Fisher } \\
\text { Chi sqaure }\end{array}$ & $\begin{array}{c}\text { Hadri LM } \\
\text { test }\end{array}$ \\
\hline Divided policy & -8.58 & -3.26 & -1.63 & 90.84 & 2.59 & 8.74 \\
p value & 0.00 & 0.00 & 0.01 & 0.01 & 0.00 & 0.00 \\
Liquidity & -12.03 & -2.12 & -1.51 & 115.70 & 4.82 & 9.01 \\
p value & 0.00 & 0.02 & 0.07 & 0.00 & 0.00 & 0.00 \\
Profitability & 2.42 & 10.68 & -1.74 & 520.15 & 41.14 & 25.11 \\
p value & 0.02 & 0.00 & 0.04 & 0.00 & 0.00 & 0.00 \\
\hline
\end{tabular}

\section{Autocorrelation Test}

By the $p$-values in table 5, the null hypothesis cannot be rejected at the 5\% significance level, which means that there is no autocorrelation in the data.

Table 6. Wooldridge test for autocorrelation in panel data

\begin{tabular}{lll}
\hline H0: & no & first-order autocorrelation \\
\hline $\mathrm{F}($ & $1, \quad 30)=0.910$ \\
& Prob $>\mathrm{F}=0.3478$ \\
\hline
\end{tabular}

\section{Specification Error Test}

Table 6 highlights the results of the Ramsey RESET test. From the findings in the table, the probability values of the computed statistics in the Ramsey RESET test are more than the threshold value of 0.05 , it implies that the model does not seem mis specified. This implies that our model was correctly specified (Studenmund, 2000).

Table 7. Ramsey RESET (test using powers ofthe fitted values of FP)

\begin{tabular}{lrr}
\hline Ho: & model has no omitted & variables \\
& $\mathrm{F}(3,296)=$ & 11.97 \\
& $\mathrm{Prob}>\mathrm{F}=$ & 0.08 \\
\hline
\end{tabular}

\section{Empirical Results and Discussion}

The results regarding the correlation results were summarized and presented in table 7. Pearson correlation results in the table showed that ownership concentration is positively related with dividend policy with a 
Journal of Business Management and Economic Research (JOBMER), Vol.4, Issue.4, pp.299-317

Pearson Correlation coefficient of $\mathrm{r}=.628$ which is significant at $\mathrm{p}<0.01$. The output also shows that ROA is positively related with dividend policy, with a coefficient of $r=.482$ which is also significant at $p<0.01$. Also, the correlation results indicated that liquidity is positively related with dividend policy as shown by a coefficient of $r=0.215$ which is significant at $p<0.01$. Besides, firm age is positively related with dividend policy, with a coefficient of $r=.360$ which is also significant at $p<0.01$. In addition, firm age is positively related with dividend policy with a Pearson Correlation coefficient of $r=.360$ which is significant at $\mathrm{p}<0.01$. The output also shows that firm size is positively related with dividend policy, with a coefficient of $r=.376$ which is also significant at $\mathrm{p}<0.01$.

To decide between fixed or random effects one can run a Hausman test where the null hypothesis is that the preferred model is random effects compared to the alternative the fixed effects (see Green, 2008). From the Hausman test Table 7 which shows summary of the results, the conclusion is that, there is a failure to reject the null hypothesis of "difference in coefficients not systematic" to determinants of dividend policy. This is because the chi-square value of 7.76 was not significant, $\mathrm{p}$-value $=0.2561$. Therefore, this implies that, effect of hypothesis is tested using the random effects model. This means that the most appropriate model is the random effects.

The regression results for the random model are as illustrated in table 7. The random model showed that profitability, liquidity, firm age and firm size explained $71.26 \%$ variation of dividend policy.

Hypothesis 1 stated that highly profitable firms will likely pay dividends. Findings showed that profitability had coefficients of estimate which was significant basing on $\beta_{1}=0.132$ (p-value $=0.000$ which is less than $\alpha$ $=0.000$ hence it was concluded that profitability had a positive and significant effect on dividend policy. This finding infers the more profitable a firms is the higher the probability for dividend payout. Thee findings are similar with Yarram and Dollery, (2015), Kimie and Pascal (2011) and Kuzucu (2015) findings that profitability positively affect dividend policy.

Hypothesis 2 stated High liquid firms will have a higher probability of paying dividends.. Findings showed that liquidity had coefficients of estimate which was significant basing on $\beta_{2}=0.029$ (p-value $=0.005$ which is less than $\alpha=0.000$ hence liquidity has a positive and significant effect on dividend policy. This suggested that the more liquid a firms is the more probability it will pay dividends.

Hypothesis 3 stipulated that highly ownership concentrated firms will have a higher probability of paying dividends. Results showed that beta coefficient for ownership was $\beta_{3}=.178$, $\mathrm{p}<.05$ inferring that hypothesis 
3 was accepted. This indicates that a highly concentrated ownership in firms will increase probability of paying dividends.

Hypothesis 4 stipulated that highly leveraged firms will have a higher probability of paying dividends. Results showed that beta coefficient for leverage was $\beta_{4}=.417, \mathrm{p}<.05$, hence the hypothesis was accepted. This shows that firm with high level of leverage will pay dividends. The findings tally with DeAngelo et al. (2004) observation that Leverage also influences the dividend behavior of companies, provided the level of the leverage is high, which means that investment in the firm is comparatively riskier in the manners of cash flow. On the other hand, the view of Jensen et al. (1992) was different in that they believed financing from equity is more attractive to firms having high dividend ratios than from debt, so low ratios of longterm debt to the book value of total assets often happen in these companies.

Table 8. Housman test

\begin{tabular}{|c|c|c|c|}
\hline & Random Effect & Fixed Effect & Correlation \\
\hline & Coef. & Coef. & \\
\hline Profitability & $.132^{* *}(0.014)$ & $.132^{* *}(0.015)$ & $.482^{* *}$ \\
\hline Liquidity & $.029^{* *}(0.01)$ & $.021(0.012)$ & $.215^{* *}$ \\
\hline Ownership & $.178^{* *}(.014)$ & $.170^{* *}(.016)$ & $.627^{* *}$ \\
\hline Leverage & $.417^{* *}(.018)$ & $.413^{* *}(.020)$ & $.700^{* *}$ \\
\hline firm age & $-0.057^{*}(0.023)$ & $-0.082(0.043)$ & $.360^{* *}$ \\
\hline Firm size & $-0.303^{* *}(0.023)$ & $-0.298^{* *}(0.029)$ & $.376^{* *}$ \\
\hline _cons & $0.116(0.519)$ & $0.155(0.429)$ & \\
\hline sigma_u & 0.011 & 0.052286 & \\
\hline sigma_e & 0.155 & 0.154525 & \\
\hline rho & 0.005 & 0.10273 & \\
\hline R-sq: within & 0.7126 & 0.7133 & \\
\hline between & 0.9444 & 0.9413 & \\
\hline overall & 0.7912 & 0.79 & \\
\hline Wald chi2(6) & 1831.73 & & \\
\hline Prob > chi2 & 0.000 & & \\
\hline $\mathrm{F}(6,447)$ & & 185.37 & \\
\hline Prob $>F$ & & 0.000 & \\
\hline \multicolumn{4}{|l|}{ Obs 449} \\
\hline \multicolumn{4}{|c|}{ Housman test } \\
\hline $\operatorname{chi2(6)}$ & \multicolumn{2}{|c|}{7.76} & \\
\hline Prob>chi2 & \multicolumn{2}{|c|}{0.2561} & \\
\hline
\end{tabular}


Journal of Business Management and Economic Research (JOBMER), Vol.4, Issue.4, pp.299-317

\section{Summary and Conclusion}

Profitability as measured by return on asset (ROA) had a positive and significant influence on the dividend policy. The results support the notion that firms that make consistent high profits are expected to pay high dividends to shareholders. The reason for this is that shareholders tend to buy shares from firms that are perceived profitable or are performing. Furthermore, if firms have adequate cash flows, it distributes its cash dividend in order to keep its shareholders contented. Firms will however be required to make their dividend payments in cash so that they are liquid enough to distribute dividends and also to remain solvent. Finally, the extent to which the banks are financed by debt has a positive influence on the dividend policy. It appears therefore that the banks are lowly leveraged as they have a propensity to pay dividends. This means that the banks are not financially constrained. As such, they are not monitored by debt holders who reduce management capability of paying dividends.

\section{Theoretical and managerial implication of the study}

In light of the study findings and conclusion of the study, it is recommended for firms to have a concentrated ownership as it leads to the distribution of a great percentage of dividends and shows a positive relation with dividends policy. Moreover, there is need for institutional ownership since they interfere less when supervising the directive role and have a preference towards the recovery of their investments through the payment of dividends. This in turn reduces the opportunistic behavior of the management.

Also, the study found profitability to influence the dividend policy. It is therefore important for banks to adopt a dividend policy that they are able to maintain even during the years that the banks report minimum profits, this is crucial because it satisfies the shareholders and avoids promising the shareholders high earnings that they cannot maintain in the future.

Moreover, liquidity positively influenced the dividend policy. This study recommends that a comprehensive assessment of the banks' immediate liquidity position should be undertaken before any dividend payout is declared to the shareholders. This is because the bank' liquidity position is of high importance since it influences the banks' current operations.

The main objective of this study was to establish the effect of bank characteristics and dividend policy among banks in Kenya. Valuable insights have been found however it is important to reflect on the 
Journal of Business Management and Economic Research (JOBMER), Vol.4, Issue.4, pp.299-317

conducted work so that further research opportunities can be pointed out. First and foremost, there is need for further research since there is limited literature on the influence of leverage on dividend policy. Also, the study utilizes only secondary data from annual reports. It is therefore recommended that in future researchers can extend the study longitudinally based on the company's website or a survey which is preferable for eliciting more detailed information on a particular subject. Finally, a further study needs to be conducted using more variables that may be relevant to this study since there is no evidence that dividend policy is entirely dependent on the four variables.

\section{References}

Abdelsalam, O., El-Masry, A.,\& Elsegini, S., (2008). Board composition, ownership structure and dividend policies in an emerging market further evidence from CASE 50. Managerial Finance. 12, 953-964.

Al Masum A. (2014) Dividend Policy and Its Impact on Stock Price - A Study on Commercial Banks Listed in Dhaka Stock Exchange. Global Disclosure of Economics and Business. 3(1)

Albitar, K. (2015). Firm Characteristics, Governance Attributes and Corporate Voluntary Disclosure: A Study of Jordanian Listed Companies. International Business Research,8(3).

Al-Najjar, B. (2009). Corporate governance and institutional ownership: evidence from Jordan", Corporate Governance. The international journal of business in society, 10(2), 176- 190.

Anil, K.,\& Kapoor, S. (2008). Determinants of dividend payout ratios - a study of Indian information technology sector. International Research Journal of Finance and Economics, 15, 63-71.

Baker, M., \&Wurgler, J. (2004).A Catering Theory of Dividends. The Journal of Finance, 59(3), 1125-1165.

Bancel, F., Bhattacharyya, N., \& Mittoo, U. R. (2009).Cross-Country Determinants of Payout Policy: European Firms, in Dividends and Dividend Policy. John Wiley \& Sons, Inc., Hoboken, NJ, USA

Belden, S., Fister, T. \& Knapp, B. (2005). Dividends and Directors: Do Outsiders Reduce Agency Costs?. Business and Society Review, 110 (2), 171-180.

Bhattacharya, S. (1979).Imperfect information, dividend policy, and 'the bird in the hand' fallacy. The Bell Journal of Economics, 10(1), 259.

Biwott, P. K. (2011). International Trade Liberalization and Economic Growth: The Role of Regulatory Policies. Kenya Institute for Public Policy Research and Analysis (KIPPRA).

Black, F. (1976). The dividend puzzle. The Journal of Portfolio Management, 2(2), 5-8.

Brav, A., Graham, J. R., Harvey, C. R., \&Michaely, R. (2005).Payout policy in the 21st century. Journal of Financial Economics, 77(3), 483-527.

Brealey, R. A., Myers, S. C., \& Allen, F. (2006).Principles of corporate finance. New York, NY: McGrawHill/Irwin. 
Breusch, T. S.,\& Pagan, A. R.,(1979). A simple test for heteroskedasticity and random coefficient variation.Econometrica,47, 1287-1294.

DeAngelo, H., DeAngelo, L., \&Skinner, D. (2004). Are dividends disappearing? Dividend concentration and the consolidation of earnings. Journal of Financial Economics, 72, 425-456.

DeAngelo, H., DeAngelo, L., \& Stulz, R. M. (2006). Dividend policy and the earned/contributed capital mix: A test of the life-cycle theory. Journal of Financial Economics, 81, 227-254.

Fan, H. \& Sundaresan, H. (2000). Debt Valuation, Renegotiation and Optimal Dividend Policy. Rev. Financ. Stud., 13(4), 1057-1099.

Gordon M. J. (1963).Optimal investment and financial policy. Journal of Finance, 18(2), 264-272.

Ho, H. (2003). Dividend policies in Australia and Japan. International Advances in Economic Research, 9(2), 91-100.

Hsiao, C. (1986). Analysis of panel data. Cambridge: Cambridge University Press.

Hsiao, C. (2007). Panel data analysis - advantages and challenges. Test, 16(1), 1-22.

Hussainey, K., Mgbame, C. O., \& Chijoke-Mgbame, A. M. (2011), Dividend policy and share price volatility: UK evidence. The Journal of Risk Finance, 12 (1), 57-68.

Jensen, G.R., Solberg D.P.,\& Zorn T.S. (1992). Simultaneous Determination of Insider Ownership, Debt and Dividend Policies. Journal of Financial and Quantitative Analysis. 27, 247-263.

Khidmat, W.,\& Rehman, M. (2014). Impact of Liquidity \& Solvency on Profitability Chemical Sector of Pakistan. Economics Management Innovation, 6 (3), 3-13.

Kwak, D.O., (2011). Three essays on unbalanced panel data Models. Unpublished Doctoral Dissertation, Michigan State University.

Lee, S. (2008), Ownership Structure and Financial Performance: Evidence from Panel Data of South Korea. Department of Economics Working Paper Series

Li, K., \& Zhao, X. (2008).Asymmetric information and dividend policy. Financial Management, 37(4), 673694.

Lintner, J. (1962). Dividends, Earnings, Leverage, Stock Prices and the Supply of Capital to Corporations. The Review of Economics and Statistics, 44(3), 243.

Miko, N. U., \&Kamardin, H. (2015).Ownership structure and dividend policy of conglomerate firms in Nigeria. Academic Journal of Interdisciplinary Studies.

Miller, M. H., \& Rock, K., (1985).Dividend Policy under Asymmetric Information. The Journal of Finance, 40(4), 1031-1070.

Miller, M., \& Modigliani, F. (1961).Dividend policy, growth, and the valuation of shares. Journal of Business, 34, 411-433.

Ofer, A. R., \& Siegel, D. R. (1987). Corporate Financial Policy, Information, and Market Expectations: An Empirical Investigation of Dividends. The Journal of Finance, 42(4), 889.

Ongore, V.O. (2011).The relationship between ownership structure and firm performance: An empirical analysis of listed companies in Kenya. African Journal of Business Management, 5 (6), 2120-2128. 
Journal of Business Management and Economic Research (JOBMER), Vol.4, Issue.4, pp.299-317

Salari, N., Abbasian, E., \& Pakizeh K., (2014).Effect of Dividend Policy Measures on Stock Price volatility in Tehran Stock Exchange. International Journal of Finance, Accounting and Economics Studies, 2(1).

Sharma, D. K., \&Wadhwa, R. (2013). Ownership structures and dividend policy - A study of Bombay stock exchange-500.Global Journal of Management and Business Studies, 3(4), 439-434.

Stouraitis, A., \& Wu, L. (2004).The impact of ownership structure on the dividend policy of Japanese firms with free cash flow problem. Retrieved from http://www.affi.asso.fr/uploads/Externe/d0/CTR_FICHIER_114_1226315600.pdf

Thanatawee, Y. (2013). Ownership Structure and Dividend Policy: Evidence from Thailand. International Journal of Economics and Finance IJEF, 5(1).

Tsuji, C. (2010). A test of the catering theory of dividends: The case of the Japanese electric appliances industry. Journal of Management Research, 2(2). 